\title{
Relevance of 'vanaprastha' of the vedic age at afternoon stage of life at present global age: a perspective
}

\begin{abstract}
There is two parts in life- forenoon and afternoon. The afternoon part of life indicates the life at post retirement. At the afternoon stage of life, individual usually follows the rules of renunciation and detachment which the Vanaprastha of the Vedic Age directed. But at present global age, the elderly population lead a highly consumerised life. The present paper attempted to explore the above differences in the lives of elderly. For this purpose 100 elderly populations of 60-70years of age living at Kolkata Metro were studied. From this study, it revealed that majority of them was suffering from various problems (physical and mental). They used to follow highly consumerised life. While a little portion of them lived with happiness because they were practicing the rules of Vanaprastha and they led a simple living with renunciation. They used to practice a spiritual living. So, it might be a path of happy aging and acceptance of death.
\end{abstract}

Keywords: afternoon stage of life, highly consumerised life, renunciation, spiritual practice \& vanaprastha.
Volume I Issue I - 2017

Harasankar Adhikari

Social Worker and Independent Scholar, India

Correspondence: Harasankar Adhikari, Social Worker and Independent Scholar, Monihar Co-operative Housing Society, Flat No-7/2, 1050/2, Survey Park, Kolkata-700075, West Bengal, India,Tel 0974803 I763, Email jaoya 123@yahoo.co.in

Received: September 21, 2016 | Published: February 22, 2017

\section{Introduction}

Human life can be divided into two phases the forenoon phase and the afternoon. If a person thought 80 years of longevity, up to 40 years would be the forenoon phase and thereafter the afternoon phase might start. The forenoon phase is important in human life because it is the basement of life for education and one individual searches for food, shelter, clothing and sensory pleasure. This is phase of earning for money making to satisfy oneself with above needs and demands. Individual human beings have to perform certain duties like marriage, rearing of family and social and citizenship responsibility. According to the rules of this phase of life, one individual lives altogether with peace and harmony in society with other fellow members. Comparing to the above, afternoon phase i.e. middle age of life is the milestone for development of detachment. It indicates to restrict the limit of activities outside for earning and it warns to perform inside activity for personality development and spiritual development. There is need of adoption of inner culture of life beyond natural work of moneymaking, social existence and family and other duties. ${ }^{1}$ But practically we find that there are so many institutions at the forenoon stage while at the afternoon stage religious institution is the only to deal this phase. Consequently, the successful aging is a burden and the absence of effective psychic hygiene leads unhappy death. ${ }^{2}$

Hinduism (dominated religion of India), a holistic and balanced religion reminds the direction of successful aging. The Vedic ages recognizes the people's need at different times of their lives. Manusmirti and other Hindu's scriptures describe four main goal in four main phases of life (Bramhacharya, Grahastha, Vanprastha and Sanyas). The Vanaprastha- the third stage indicates particularly the way of successful aging, especially for the elderly in higher social hierarchy. It postulates the guidelines during just preretirement and post retirement of life. After achievement of success in working, a person should denote for the society and family. He should dedicate himself for social service, helping others within his/her community by sharing his/her expertise and experience. It would lead a nonconsumer life with a peaceful death.

But the state of living of elderly in the Vedic age and at present Global age is distinctly making differences. In present context, elderly face various problems such as:

a. physical fitness and health problems,

b. financial problems,

c. psychological problems and

d. problems of interaction in a social or familysetting Psychosocial and environmental problems include feeling of neglect, loss of importance in the family, loneliness and feeling of un-wontedness in family as well as society, feeling of inadequacy and obsolescence of skills, education, and expertise. ${ }^{3}$ These aspects are somewhat interdependent in nature; each aspect may affect the quality and quantity of the problems in other categories. ${ }^{4}$

The reasons for this critical living of elderly are associated with globalization and Global cultural bound syndrome. ${ }^{5}$ This gives birth of the consumer class for which the people change their lifestyle and life choices irrespective of their age and gender. Elderly population is not beyond the tract of consumerism. At their post retirement, they also adopt a high consumerised life style which results soaring rates of heart diseases and diabetics, surging health cost and a lower quality of day to day life. Their philosophy of happiness is like a wantcreated consumption. ${ }^{6}$ Essentiality of their living suffers from mental illness so that they do not like to follow the age-related restriction or limitation for their painless survival. ${ }^{7}$ They prefer to take highly processed food which is being wrapped with loneliness, workless time passed in their leisure and truncated network of social relationship. ${ }^{8}$ There is no alternative engagement in their post retirement beyond watching television and such entertainment. 
Consequently, major developmental crises associated with aging include: dependence, isolation, illness, loss, retirement, and death. The overall situation has been changed the living status of the elderly in India. So, the objective of the study was to compare the lives of elderly following the rules of Vanaprastha for a direction of peaceful living and peaceful death and the elderly who were in highly consumerised life in global In.

\section{Methods}

The simple purposive random sampling was employed for the study in respect of living status, economic status and health status (physical and mental) of the elderly of 60-70 years of age. The interview schedule was used to collect information. Simultaneously for qualitative analysis, a participatory observation on life experiences and relational patterns within family members and their attitude was considered. The quantitative and qualitative data were gathered from 100 elderly (out of which, 25 informants were female at a ratio $3: 1)$ living in a new urban housing colony of Kolkata city. These households settled due to their economic purpose with the benefits of the urban life. They had limited contact with their natal families. They had accommodated in their households with their immediate younger family members, alone with their marital counterpart, with their maidservant or a relative.

\section{Result and discussion}

\section{Living status of the elderly}

We find that $70 \%$ of the informants were alone living with their conjugal partners with the assistance of domestic helps and their offsprings were living separately. There were two reasons behind this problem. Firstly, 58\% of their off-springs had settled themselves outside the city and the off-springs of rest informants lived separately within the same city because either their off-spring did not take responsibility of looking after or they were unable to adjust with their family members. They had very infrequent contact with their offspring and relatives. On the other part, $30 \%$ of the informants lived with their off-spring with their conjugal partner.

In this study, the informants were economically self-dependent. Either they had financial planned for their retired lives or they were pensioners. Their conjugal partners were also under their financial plan.. They were not burden to their off-springs. But they used to extend their help to their off-spring during any crisis or emergency. From food, clothing, health care and others any liability and financial responsibility they managed themselves.

The (Table 1). Referred that $28 \%$ male informants were public servants and among them $6 \%$ had below matriculation level education while $22 \%$ elderly had matriculation and above education. Secondly pattern of employment showed that $21 \%$ male informants were employees in private sectors where $3 \%$ of them were more than the below matriculate informants. Out of $20 \%$ business men, $12 \%$ of them were matriculate and above educational experience. Thereafter, we find that $8 \%$ were in other jobs and among them $6 \%$ informants had matriculation and above education. Among the female elderly population, in this study, 3 , out of 25 were public servants and they had matriculation and above education. Rest of them was homemaker.

Table I Education and occupation of the informants elderly

\begin{tabular}{|c|c|c|c|c|c|}
\hline \multirow[t]{3}{*}{ occupation } & \multicolumn{4}{|c|}{ Education } & \multirow{3}{*}{$\begin{array}{l}\text { Total } \\
(n, \%)\end{array}$} \\
\hline & \multicolumn{2}{|c|}{ Below matriculation } & \multicolumn{2}{|c|}{ Matriculation and above } & \\
\hline & $M(n, \%)$ & $F(n, \%)$ & $M(n, \%)$ & $F(n, \%)$ & \\
\hline Service in public sectors & $6(6)$ & - & $22(22)$ & $3(3)$ & $3 I(3 \mid)$ \\
\hline Private sectors' employee & $9(9)$ & - & $12(12)$ & - & $2 I(2 I)$ \\
\hline Business & $8(8)$ & - & $12(12)$ & - & $20(20)$ \\
\hline Homemaker & - & $6(6)$ & - & $16(16)$ & $22(22)$ \\
\hline Others & $2(2)$ & - & $6(6)$ & - & $8(8)$ \\
\hline Total & $25(25)$ & $6(6)$ & $50(50)$ & $19(19)$ & $100(100)$ \\
\hline
\end{tabular}

\section{Health status of the elderly}

The (Table 2) shows that majority of the studied elderly were in health problems. Among them $85 \%$ 9ncluding $21 \%$ female elderly were suffering from life style diseases i.e. heart diseases, hypertension, diabetes and high blood pressure, etc. Of them $78 \%$ (including $20 \%$ female) elderly had physical mobility problem and they were mentally ill.

They lived with the main support of medical observation and medical therapy and they were facing the problems of isolation and negligence from their immediately family. Their alternative

engagement limited to self care and management unhealthy living (consuming food and watching television).

On the other part, 15 elderly ( 10 male +5 female) had no such problems like above population. They had little problems fully related to according to them age related. They did not mind for this and they did not believe to take help of medical therapy for this. They usually passed their whole with different activities with spiritual practices. They preferred to detach from any emotional affiliation and they believed in simple living and renunciation was the key tool of their happiness. 
Table 2 Health problems of informants

\begin{tabular}{|c|c|c|c|}
\hline Health problems & $\begin{array}{l}\text { Male } \\
(n, \%)\end{array}$ & $\begin{array}{l}\text { Female } \\
(n, \%)\end{array}$ & $\begin{array}{l}\text { Total } \\
(n, \%)\end{array}$ \\
\hline Life style related diseases i.e. heart disease, hypertension, diabetes, high blood pressure & $64(64)$ & $2 I(2 I)$ & $85(85)$ \\
\hline Problem of physical mobility and mental illness & $58(58)$ & $20(20)$ & $78(78)$ \\
\hline No such problems & $10(10)$ & $5(5)$ & $15(15)$ \\
\hline
\end{tabular}

\section{Happiness/Unhappiness in end of life}

Happiness/un-happiness is a mental state and there is no parameter of measurement of it. Only it depends on individual's need and demands and its fulfillment. The level of satisfaction is determined by it. We see when an individual does not able to access his/her demand of life for enjoyment, he/she feels unhappy comparing to other fellow members. Materials need and demand in consumerised life do not bring happiness and peace in mind and life. It only increases one's greed and mental anxiety.

The studied of individual elderly revealed their unhappiness for non-fulfillment of their demand at their end part of life. This elderly population adopted the life of enjoyment and they were trying to compete younger. They did not follow the rules of renunciation.

Case. 1: He lived with his wife with the help of a maidservant. He had two children ( one male and one female). Both of them lived within the city separately after their married. Occasionally they used to visit him. He and his wife were suffering from hypertension, high blood pressure and mental anxiety. They felt isolation of their off-springs and they used to blame their fortune for this. On the other hand, they used to lead a highly consumerised life with highly processed food and they passed their time after watching television. Her wife only performed some religious act in particular time of a day. His viewed that life at end was for enjoyment.

While in the same study, the elderly informants who followed the principle of detachment and renunciation were comparatively happy at their afternoon phase of life. They left their greediness as well as materials demand was less essential than spiritual demand and they practiced low consumption. It brought happiness in their daily living. Their physical and mental were in good state. Their belongingness and demand were spiritual based and follow the rules of Vanaprastha. The renunciation and simple living style were their secrete of mental well-being.

Case 2: He lived with his conjugal partner and one maid servant was assisting them. Before 10 years, he had shared his all business responsibilities to his two sons who were living separately and they used to visit their parents for their guidance time to time. Throughout the day, he engaged himself in different social activities and spiritual acts with the assistance of his wife. He adopted a simple living. He had no such life style diseases or unhappiness except age-related problems. According to him these problems were the signal of end of life. His materials demand was renunciated. He followed the rules of Vanaprastha with welcoming and accepting the death happily.

\section{Conclusion}

The forenoon phase of life is embarked with enjoyment and there are some duties and responsibilities to be performed in this phase. It influences materials need and demand in changing scenario. But at the afternoon phase of life, there is need of renunciation and detachment emotionally and functionally. Simple living style with practice of spirituality helps to lead a peaceful happy life. There is no place of greed in this phase. It is the way of practice of Vanaprastha. In this study, we find that majority of the elderly was submerged with greed and they were seeking attachment of their off-spring. Highly consumerised life and want created consumption influenced their unhappy life style. It was the prime cause of their painful living.

Further, we find that a little portion of them was practicing the path of Vanaprastha with simple living and spiritual practice. They were preparing themselves to accept death happily. So, there is need of spiritual practice and teaching in the line of Vanaprastha to renunciate and detach from the practice at forenoon phase.

\section{Acknowledgements}

None.

\section{Conflict of interest}

Author declares there is no conflict of interest in publishing the article.

\section{References}

1. Jung CG. Modern Man in Search of a Soul. A Harvest Book. Harcourt Inc. New York; 1933

2. Kubler Ross E. On Death and Dying. Scribner. New York; 2003.

3. Willing JV, Chadha NK. Social aging in a Delhi neighbourhood. Connecticut and London. Westport. Bergin and Garvey analyses the pros and cons of elderly life in urban area. Delhi, India; 1999.

4. Irudaya RS, Mishra US, Sarma PS. India's Elderly. Burden Or Challenge? New Delhi. Sage Publications and London. Thousand Oaks. 1999.

5. Banks CG. Culture in Culture Bound Syndrome. The Case of Anorexia Nervosa. Social Sciences and Medicines. 1992;34(8):867-884.

6. Smith A. The Theory of Moral Sentiments. Indianapolis. Liberty Fund. 1982.

7. Jamuna D. Ageing In Developing Countries India. Ageing International. 2000;25(4):16-31.

8. Adhikari H. Elderly in Truncated Social Network. Agonized Living Status Towards Counting the Days of Death. Indian Journal of Gerontology. 2013;27(3):530-540

9. Argyle M. The Psychology of Happiness. Rutledge. New York, USA; 2009.

10. O'Flaherty W.D. The Rig Veda, Penguin, New Delhi, India; 2002.

11. Sara J, Czaja, Joseph Sharit. The Aging of the Population. Opportunities and Challenges For Human Factors Engineering. The Bridge. 2009;39(1):16-31. 